\title{
Evaluation of different feed intake models for dairy cows
}

\author{
S. J. Krizsan, ${ }^{* 1}$ A. Sairanen, $†$ A. Höjer, ${ }^{*}$ and P. Huhtanen ${ }^{*}$ \\ ${ }^{*}$ MTT Agrifood Research Finland, North Savo Research Station, FIN-71750 Maaninka, Finland \\ †Swedish University of Agricultural Sciences, Department of Agricultural Research for Northern Sweden, S-901 83 Umeå, Sweden
}

\section{ABSTRACT}

The objective of the current study was to evaluate feed intake prediction models of varying complexity using individual observations of lactating cows subjected to experimental dietary treatments in periodic sequences (i.e., change-over trials). Observed or previous period animal data were combined with the current period feed data in the evaluations of the different feed intake prediction models. This would illustrate the situation and amount of available data when formulating rations for dairy cows in practice and test the robustness of the models when milk yield is used in feed intake predictions. The models to be evaluated in the current study were chosen based on the input data required in the models and the applicability to Nordic conditions. A data set comprising 2,161 total individual observations was constructed from 24 trials conducted at research barns in Denmark, Finland, Norway, and Sweden. Prediction models were evaluated by residual analysis using mixed and simple model regression. Great variation in animal and feed factors was observed in the data set, with ranges in total dry matter intake (DMI) from 10.4 to $30.8 \mathrm{~kg} / \mathrm{d}$, forage DMI from 4.1 to $23.0 \mathrm{~kg} / \mathrm{d}$, and milk yield from 8.4 to $51.1 \mathrm{~kg} / \mathrm{d}$. The mean biases of DMI predictions for the National Research Council, the Cornell Net Carbohydrate and Protein System, the British, Finnish, and Scandinavian models were -1.71, $0.67,2.80,0.83,-0.60 \mathrm{~kg} / \mathrm{d}$ with prediction errors of $2.33,1.71,3.19,1.62$, and $2.03 \mathrm{~kg} / \mathrm{d}$, respectively, when observed milk yield was used in the predictions. The performance of the models were ranked the same, using either mixed or simple model regression analysis, but generally the random contribution to the prediction error increased with simple rather than mixed model regression analysis. The prediction error of all models was generally greater when using previous period data compared with the observed milk yield. When the average milk yield over all periods was used in the predictions of feed intake, the increase in prediction error of

Received October 3, 2013.

Accepted December 20, 2013.

${ }^{1}$ Corresponding author: sophie.krizsan@slu.se all models was generally less than when compared with previous period animal data combined with current feed data. Milk yield as a model input in intake predictions can be substantially affected by current dietary factors. Milk yield can be used as model input when formulating rations aiming to sustain a given milk yield, but can generate large errors in estimates of future feed intake and milk production if the economically optimal diet deviates from the current diet.

Key words: dairy cow, feed intake, model evaluation, prediction

\section{INTRODUCTION}

Feed intake is the most important single nutritive factor influencing the production of dairy cows (Mertens, 1994; Huhtanen et al., 2011). Additionally, feed is often the largest single cost item to dairy farmers. Therefore, much research attention has been focused on developing accurate models to predict feed intake. Most published feed intake models are empirical and based on multiple regression equations; they are either solely based on animal factors or combined with diet characteristics to varying complexity (Ingvartsen, 1994; Huhtanen et al., 2011; Volden et al., 2011). The development of feed intake prediction models have generally been restricted to animal and diet characteristics available at the time of ration formulation. However, milk yield at the time of feeding is related to the current feed ration, and observed milk yield has experimentally been shown not to be useful in predictions of the intake potential of a new diet (Friggens et al., 1998). Ingvartsen (1994) reported that milk yield is not actually known at the time of prediction. Keady et al. (2004a) further discussed that using the actual milk yield in the feed intake predictions only aims at sustaining a given level of milk yield. Different approaches have been suggested to circumvent this problem. The herbage intake prediction model by Faverdin et al. (2011) forecasts potential milk production from a theoretical lactation curve using only DIM, parity, and potential production at peak (or total 305-d milk production). Huhtanen et al. (2011) tried to overcome the problem by using a standardized milk yield in their feed intake model (i.e., observed milk yield was 
adjusted to correspond to a standard diet fed at 150 DIM). Zom et al. (2012a) chose an approach where they simply avoided the use of model inputs related to animal outputs, such as milk yield (MY) and BW, and instead used easy-to-measure inputs, such as parity, DIM, and days of pregnancy, that are directly available at commercial farms. Further, the interactions between environmental, feed, and animal factors theoretically limit the use of any intake model; empirical models are only valid for similar conditions to those they have been developed from.

The Nordic feed evaluation system introduced a semimechanistic approach in the prediction of voluntary feed intake by cattle (Volden et al., 2011). The system aims at separating animal and feed factors so that animal factors determine the intake capacity of the diet and feed factors control the physical regulation or determine the fill value of the diet. In any model predicting feed intake from both animal and feed factors, it is important that the effects are integrated independently of each other (i.e., that animal variables are independent of the diet fed to the animals), otherwise the estimates of the true animal and diet effects can be biased.

Our aim was to evaluate different feed intake prediction models of varying complexity (i.e., restricted to animal factors or comprising also diet characteristics) using individual data of lactating cows subjected to experimental dietary treatments in periodic sequences (i.e., change-over trials). The choice of models evaluated was restricted by the data required, as model inputs from the experiments pooled in the database (primarily related to the dependency of feed related factors in the prediction model), and by applicability to Nordic conditions. We aimed to use the observed animal and feed data of each period in the trials to predict intake that has been adapted traditionally in evaluations of feed intake prediction models. In addition, we combined previous period animal data with current feed data within each experiment to illustrate the situation, and amount of available data, when formulating rations for dairy cows in practice. This approach was used to illustrate the robustness of the models because the production response of the current diet was not known.

\section{MATERIALS AND METHODS}

\section{Database Construction}

The animals used in the experiments included in the database were registered and cared for according to guidelines approved by the local Research Animal Care and Use Committee, and the experiment was carried out in accordance with the laws and regulations con- trolling experiments performed with live animals in the country where the experiment was conducted.

A data set was constructed from 24 change-over trials (i.e., the cows were subjected to dietary treatments in periodic sequences) conducted in Denmark $(\mathrm{n}=2)$, Finland $(\mathrm{n}=15)$, Norway $(\mathrm{n}=2)$, and Sweden $(\mathrm{n}=$ 5 ). The aims of the trials were to study production responses of lactating cows fed various experimental diets $(\mathrm{n}=179)$. Individual cow observations of 575 Danish Holstein, Finnish Ayrshire, Norwegian Red, and Swedish Red cows on feed intake and milk production parameters were pooled in the database $(\mathrm{n}=2,161)$. A total of 42 missing cow observations were recorded in 10 of the 24 experiments, mostly due to mastitis and errorneous concentrate intake and milk production recordings. Three additional data points were excluded from the analysis due to cows less than 30 DIM and our objective to study feed intake at the established lactation (Huhtanen et al., 2011). The prerequisites for an experiment to be included in the analysis were ad libitum feeding of either forage or TMR throughout the whole experiment and individual recordings from each cow and period for the animal-dependent parameters required for the different intake models. The aim was to collect data from trials comprising different forage types, diet CP concentrations, concentrate feeding levels, and generally covering a wide range in total DMI (TDMI).

In the database, 4 experiments were primarily targeted on forage source, 7 studies dealt with different sources or levels of concentrate supplementation, and 13 studies had factorial arrangement of treatments including both forage type and level of concentrate supplementation. The animal-dependent parameters registered for each cow in each period were forage and concentrate DMI (CDMI), parity, DIM, BW, MY, and concentrations of protein, fat, and lactose in the milk. The yield of ECM was calculated according to Sjaunja et al. (1990). The experimental diets included in the database comprised different types of forages - grass hay, grass, legume (white and red clover and birdsfoot trefoil; Trifolium repens and pratense and Lotus corniculatus, respectively), whole crop (barley and wheat; Hordeum vulgare and Triticum aestivum, respectively), corn (Zea mays), and mixtures of grass and legume silages - and were fed at different levels of concentrate feeding. Grass silages were mostly made from the first cut $(\mathrm{n}=43)$, but second $(\mathrm{n}=7)$ and third cut $(\mathrm{n}=$ 2) grass silages were also fed in 4 experiments. In one experiment, the different cuts of legume-grass silages (n $=3$ ) were all fed in mixtures. Grass species included in the diets were all cool season grasses originating from northern Europe. The dietary information required from each experiment were proportion of first harvest 
and regrowth of the grass silage, proportions of legume or whole crop silage in the diet, concentrations of DM, OM, CP, NDF, the total fermentation acids (TA; sum of lactic, acetic, propionic, and butyric acid), and $\mathrm{NH}_{3-}$ $\mathrm{N}$ in the forage.

The digestible OM in the DM (D-value) of the forages was either determined in vivo in sheep fed at maintenance level of feeding, or estimated from in vitro values and known relationships to in vivo OM digestibility. The concentrates fed with the forages differed both in amount and composition, but were offered either at fixed levels or proportions throughout a study. Further prerequisites for inclusion of an experiment was that the concentrate ingredient composition and concentrations of $\mathrm{ME}, \mathrm{CP}, \mathrm{NDF}$, and fat in the concentrate were given or could be estimated. The effective protein degradability in the concentrate (CEPD) was calculated from concentrate ingredient composition and tabulated degradability values according to MTT (2012). The concentrate was fed either mixed with the silage as a TMR $(\mathrm{n}=8)$, separately $(\mathrm{n}=14)$, or both $(\mathrm{n}=2)$, and varied in composition between the trials but was generally based on cereals (barley and oat; Hordeum vulgare and Avena sativa, respectively), a protein feed (rapeseed or soybean meal; Brassica napus and Glycine max, respectively), and sugar beet pulp (Beta vulgaris). Concentrations of starch and sugar in forages and concentrates when not analyzed were determined by subtracting the content of NDF, $\mathrm{CP}$, and fat from the $\mathrm{OM}$ in the $\mathrm{DM}$, and additionally the concentration of TA was subtracted from forage OM. The concentration of ether extracts in forages when not given was determined from a relationship to OM digestibility established from relevant forages in the NorFor (2013) feedtable as $0.081 \times \mathrm{OM}$ digestibility -22.7 . The list of studies used in this meta-analysis is given in Appendix.

\section{Feed Intake Models and Calculations}

Five published feed intake prediction models were evaluated using the individual cow data from all 24 trials. The NRC (2001) and the Cornell Net Carbohydrate and Protein System (CNCPS; Fox et al., 2004) include only animal parameters (Eq. 1 and 2, respectively) in the prediction of TDMI, whereas Vadiveloo and Holmes (1979; Eq. 3) introduced CDMI as a diet factor in addition to animal parameters:

$$
\begin{aligned}
& \mathrm{TDMI}=\left[\left(0.372 \times \mathrm{FCM}+0.0968 \times \mathrm{BW}^{0.75}\right)\right. \\
& \times\{1-\exp [-0.192 \times(\mathrm{WL}+3.37)]\}]
\end{aligned}
$$

$$
\begin{gathered}
\mathrm{TDMI}=(0.0185 \times \mathrm{BW}+0.305 \times \mathrm{FCM}) \times \mathrm{Lag} \\
\mathrm{Lag}=1-\exp [(0.564-0.124 \times \mathrm{PMY}) \times(\mathrm{WL}+\mathrm{P})],
\end{gathered}
$$

$$
\begin{gathered}
\mathrm{TDMI}=0.076+0.404 \times \mathrm{CDMI}+0.013 \times \mathrm{BW} \\
-0.129 \times \mathrm{WL}+4.12 \times \log (\mathrm{WL})+0.14 \times \mathrm{MY},
\end{gathered}
$$

where TDMI, FCM, MY, and CDMI are in kilograms per day; $\mathrm{BW}$ is in kilograms; $\mathrm{WL}=$ week of lactation; and $\mathrm{PMY}=$ month postcalving when peak milk yield occurred $(1,2$, or 3$)$ and $\mathrm{P}=2.36$ for $\mathrm{PMY}=1$ and 2 , and $\mathrm{P}=3.67$ for $\mathrm{PMY}=3$. As the exact date of PMY was not recorded, a default value of 2 was used. The model also has temperature and mud adjustment factors, but all studies were conducted in a temperate climate and within experimental dairy barns, and therefore the temperature and mud factors were judged as not necessary in these predictions. Furthermore, 2 of today's most advanced models for intake predictions by cattle are used in the Nordic countries.

Huhtanen et al. (2008) developed a TDMI index and recently included animal factors (i.e., milk yield, BW, and DIM) in the intake prediction model (Huhtanen et al., 2011; Eq. 4). Equation 4 is an empirical model, but milk yield is made independent of the diet intake potential and nutritive value by introducing the standardized ECM (sECM) in the predictions.

$$
\begin{gathered}
\text { TDMI }=-2.9+0.258 \times \mathrm{sECM}+0.0148 \times \mathrm{BW} \\
-0.0175 \times \mathrm{DIM}-5.85 \times \exp (-0.03 \times \mathrm{DIM}) \\
+0.09 \times \mathrm{TDMI} \text { index; } \\
\text { sECM }=\text { observed } \mathrm{ECM}+0.131 \\
\times(100-\mathrm{TDMI} \text { index })+0.142 \times(90-\mathrm{MP}) \\
-0.0481 \times(150-\mathrm{DIM})+6.96 \times \exp (-0.07 \times \mathrm{DIM}) ; \\
\text { TDMI index }=\text { SDMI index }+ \text { CDMI index }-100 ;
\end{gathered}
$$$$
\text { SDMI index }=100+10 \times[(\mathrm{D} \text {-value }-680) \times 0.0170
$$$$
-(\mathrm{TA}-80) \times 0.0128+[0.0198 \times(\mathrm{DM}-250)
$$$$
\left.-0.00002364 \times\left(\mathrm{DM}^{2}-250^{2}\right)\right]-0.44 \times \mathrm{a}
$$$$
+4.13 \times \mathrm{b}-2.58 \times \mathrm{b}^{2}+5.90 \times \mathrm{c}
$$$$
\left.-6.14 \times \mathrm{c}^{2}-0.0023 \times(\mathrm{NDF}-550)\right] \text {; }
$$ 
$\mathrm{CDMI}$ index $=100+10 \times[(\mathrm{CDMI}-0.1629 \times \mathrm{CDMI}$

$$
\begin{gathered}
\left.-0.018823 \times \mathrm{CDMI}^{2}-5.49\right)+[(0.9474 \times \mathrm{CCPI} \\
\left.\left.-0.4965 \times \mathrm{CCPI}^{2}\right)-2.02 \times(\mathrm{CEPD}-0.74)\right] \\
+0.00225 \times(\mathrm{CNDF}-250)-0.0103 \times(\mathrm{Cfat}-40) \\
-0.0058 \times(\mathrm{CDMI}-8.0) \times(\mathrm{SDMI} \text { index }-100)], \quad[4]
\end{gathered}
$$

where SDMI = silage DMI index according to Huhtanen et al. (2007); TA is in grams per kilogram of DM; CDMI index was calculated according to Huhtanen et al. (2008); a, b, and c are the proportions of regrowth, legume, and whole-crop cereal silages in total silage $\mathrm{DM}$; CCPI $=$ supplementary concentrate $\mathrm{CP}$ intake $(\mathrm{kg} / \mathrm{d} ; \mathrm{CP}>170 \mathrm{~g} / \mathrm{kg}$ of $\mathrm{DM})$; CEPD is in grams per gram; $\mathrm{CNDF}=$ concentrate $\mathrm{NDF}$ concentration in grams per kilogram of DM; and Cfat $=$ concentrate fat concentration in grams per kilogram of DM. Volden et al. (2011) presents the other Nordic feed intake model (Eq. 5), which is based on the hypothesis of a biphasic feed intake regulation according to Mertens (1994). The model assumes that a dairy cow eats to meet its energy requirement providing that the physical intake capacity (IC) is not exceeded and equals the total feed intake expressed in fill units (FV_intake). The TDMI prediction is based on the general assumption

$$
\begin{gathered}
\mathrm{IC}=\mathrm{FV} \_ \text {intake } \\
\mathrm{IC}=a \times \mathrm{DIM}^{0.134} \times \exp ^{-0.0006 \times \mathrm{DIM}-\mathrm{DIM}^{-0.55}} \\
+0.091 \times \mathrm{ECM}+(\mathrm{BW}-f) \times 0.006 ; \\
\mathrm{FV} \_ \text {intake }=\Sigma \mathrm{DMI}+\times 0.22+\Sigma \mathrm{DMI}_{j} \times \mathrm{FV}_{j} \\
\times \mathrm{FV} \_\mathrm{SubR}+\mathrm{FV} \_\mathrm{MR},
\end{gathered}
$$

where $a$ and $f$ are regression coefficients for either primiparous or multiparous large dairy breeds according to Volden et al. (2011); FV_intake = diet fill value determined from a fixed fill value of concentrates; $\mathrm{DMI}_{i}$ $=\mathrm{DMI}$ of concentrate $i$; and from $\mathrm{DMI}_{j}=\mathrm{DMI}$ of forage $j ; \mathrm{FV}_{j}=$ fill value of forage $j$ that are multipled by FV_SubR = substitution rate factor between 0 and 1; and FV_MR = metabolic regulation factor. The $\mathrm{FV}_{j}$ is determined from forage $\mathrm{OM}$ digestibility and $\mathrm{NDF}$ concentration according to Volden et al. (2011). Additionally, the fill values of grass silages are corrected for TA and $\mathrm{NH}_{3}-\mathrm{N}$ according to the correction for fermentation quality published by Huhtanen et al. (2002) in their previous SDMI index. Very small or zero values of silage $\mathrm{NH}_{3}-\mathrm{N}$ will give a large effect on the logarithmic scale and erroneous effect on the fill value correction in the NorFor system. Therefore, if $\mathrm{NH}_{3}-\mathrm{N}$ was smaller than $12 \mathrm{~g} / \mathrm{kg}$ of total $\mathrm{N}$ it was set equal to $12 \mathrm{~g} / \mathrm{kg}$ of total $\mathrm{N}$ that was equal to the lowest observed value in the data. The FV_SubR and FV_MR were calculated according to Volden et al. (2011) based on the starch and sugar concentrations in the diet and total dietary intake of starch and sugar, and mean basis forage fill value, respectively.

\section{Statistical Analysis}

The model evaluation was conducted using mixed model regression. All data were analyzed using the MIXED procedures (SAS 2002-2003, Release 9.2; SAS Institute Inc., Cary, NC) by the following model:

$$
\begin{gathered}
\mathrm{Y}=\mathrm{B}_{0}+\mathrm{B}_{1} \mathrm{X}_{1 i j}+b_{0}+b_{1} \mathrm{X}_{1 i j}+\mathrm{B}_{2} \mathrm{X}_{2 i j} \\
+\ldots+\mathrm{B}_{n} \mathrm{X}_{n i j}+e_{i j},
\end{gathered}
$$

where $\mathrm{B}_{0}, \mathrm{~B}_{1} \mathrm{X}_{1 i j}, \mathrm{~B}_{2} \mathrm{X}_{2 i j} \ldots \mathrm{X}_{n i j}$ are the fixed effects and $b_{0}, b_{1}$, and $e_{i j}$ are the random experiment effects (intercept, slope and error); and $i=1 \ldots n$ studies and $j=1 \ldots n_{i}$ values. The actual observed individual milk yield was combined with current feed data, individual milk yield data from the previous period was combined with current feed data, or average individual milk yields across all periods were combined with current feed data to illustrate 3 different approaches to milk yield as input variable in feed intake predictions. Data from the first period in all trials was not included in this comparison to be able to evaluate the performance of the prediction models from the same number of observations. Model adequacy was controlled by generating residual values from observed minus predicted values from the mixed model regression. The predicted values were centered by subtracting the mean of all predicted values from each prediction within each feed intake model. This transformation centered the data points to a mean value of zero. The slope and intercept estimates in the regression is thereby made orthogonal and will allow for a proper interpretation of the regression model. Residual values were calculated from observed feed intake minus the model predicted feed intake. Prediction equations were evaluated by regressing residual values on the predicted values. Mean biases were assessed by using the intercepts of the regression equations, and the slopes of the regression equations were used to determine the presence of linear biases (St-Pierre, 2003). Mean square prediction error was divided into 3 components due to mean bias, linear bias (the deviation of the slope from 1), and random variation of around the regression line (Bibby and Toutenberg, 1977). Root mean square prediction error (RMSPE) was calculated as 


$$
\text { RMSPE }=\sqrt{\frac{\sum(\text { Observed TDMI }- \text { Predicted TDMI })^{2}}{n}}
$$

Additionally, the concordance correlation coefficient (CCC) was used in model evaluation. The CCC evaluates the agreement between paired readings and takes into account any change in SD between predicted and observed values and deviations from $\mu$ (Lin, 1989).

\section{RESULTS}

\section{Description of the Database}

The description of the whole individual cow data set and diet characteristics used for the evaluation of the different feed intake models for dairy cows is presented in Table 1. This data set represented a great variation in both ration composition and animal and feed factors of relevance for feed intake predictions. The reduced data set (i.e., deletion of data from the first period of all trials) were used to evaluate the different feed intake prediction models on an equal number of observations when both the actual observed values of milk yield and the previous period values of milk yield were used. The reduced data set displayed as much variation in animal and feed characteristics as the whole data set. Few differences were observed between the data sets, and the most pronounced changes were an increased minimum level of intake of NDF to $4 \mathrm{~kg} / \mathrm{d}$ and of average DIM from 134 to 144 as well as a decrease in maximum milk yield to $48.9 \mathrm{~kg} / \mathrm{d}$ and in milk protein to $63.1 \mathrm{~g} / \mathrm{kg}$.

\section{Evaluation of Feed Intake Models}

The evaluation of source of bias and prediction error of the different intake prediction models with mixed and simple model regression of individual cow data using either the actual observed milk yield, the previous period milk yield, or average individual milk yield across periods combined with current feed data are presented in Tables 2, 3, and 4. All evaluated models displayed a mean bias despite applied method of milk yield as input variable $(P \leq 0.03$; Tables 2,3 , and 4$)$. The NRC (2001) and the Nordic feed intake model by Volden et al. (2011) generally over-predicted total feed

Table 1. Description of the individual cow data and diet characteristics in the database used in evaluation of the different feed intake models for dairy cows $(\mathrm{n}=2,116)$

\begin{tabular}{|c|c|c|c|c|}
\hline Item & Mean & SD & Minimum & Maximum \\
\hline \multicolumn{5}{|l|}{ DMI $(\mathrm{kg} / \mathrm{d})$} \\
\hline Forage & 12.7 & 2.49 & 4.1 & 23.0 \\
\hline Concentrate & 8.3 & 2.42 & 2.5 & 16.5 \\
\hline Total & 21.1 & 3.12 & 10.4 & 30.8 \\
\hline $\mathrm{CP}$ & 3.5 & 0.68 & 1.5 & 5.8 \\
\hline NDF & 9.0 & 1.52 & 2.9 & 13.6 \\
\hline \multicolumn{5}{|c|}{ Silage composition (g/kg of DM, unless otherwise noted) } \\
\hline $\mathrm{DM}(\mathrm{g} / \mathrm{kg})$ & 277 & 118.5 & 37 & 863 \\
\hline $\mathrm{CP}$ & 149 & 28.8 & 80 & 272 \\
\hline NDF & 540 & 68.5 & 292 & 659 \\
\hline D-value ${ }^{1}$ & 674 & 37.4 & 588 & 757 \\
\hline${\text { Total } \text { acids }^{2}}$ & 68 & 29.5 & 0 & 149 \\
\hline $\mathrm{NH}_{3}-\mathrm{N}(\mathrm{g} / \mathrm{kg}$ of total $\mathrm{N})$ & 63 & 27.0 & 12 & 137 \\
\hline \multicolumn{5}{|c|}{ Concentrate composition ( $\mathrm{g} / \mathrm{kg}$ of DM) } \\
\hline $\mathrm{CP}$ & 186 & 31.2 & 108 & 299 \\
\hline $\mathrm{NDF}$ & 254 & 39.7 & 162 & 396 \\
\hline Fat & 48 & 16.2 & 23 & 125 \\
\hline \multicolumn{5}{|c|}{ Concentration in total diet ( $\mathrm{g} / \mathrm{kg}$ of $\mathrm{DM})$} \\
\hline $\mathrm{CP}$ & 164 & 20.4 & 110 & 251 \\
\hline $\mathrm{NDF}$ & 428 & 50.1 & 277 & 563 \\
\hline Metabolizable protein & 94.7 & 5.98 & 78.0 & 112.2 \\
\hline \multicolumn{5}{|l|}{ Production parameters } \\
\hline DIM & 134 & 52.8 & 35 & 364 \\
\hline Milk (kg/d) & 29.6 & 6.38 & 8.4 & 51.1 \\
\hline $\mathrm{ECM}^{3}(\mathrm{~kg} / \mathrm{d})$ & 30.6 & 5.90 & 10.1 & 52.3 \\
\hline $4 \%$ FCM $(\mathrm{kg} / \mathrm{d})$ & 30.4 & 6.22 & 9.7 & 53.0 \\
\hline Milk fat $(\mathrm{g} / \mathrm{kg})$ & 42.2 & 6.22 & 25.8 & 66.6 \\
\hline Milk protein $(\mathrm{g} / \mathrm{kg})$ & 34.7 & 5.24 & 22.9 & 65.0 \\
\hline $\mathrm{BW}(\mathrm{kg})$ & 612 & 70.3 & 443 & 850 \\
\hline
\end{tabular}

${ }^{1} \mathrm{D}$-value $=$ concentration of digestible $\mathrm{OM}$ in the DM.

${ }^{2}$ Total acids $=$ concentrations of lactic acid + acetic acid + propionic acid + butyric acid in the DM.

${ }^{3}$ Calculated according to Sjaunja et al. (1990). 
intake, else the observed TDMI was greater than the predicted TDMI by all other models (Tables 2, 3, and 4). The Nordic feed intake model by Volden et al. (2011) was most accurate when using the actual observed milk yield in the predictions, but displayed the strongest slope bias (negative) of all models evaluated in this study $(P<0.01$; Table 2$)$. The TDMI model developed by Huhtanen et al. (2011) was the only model that did not display any slope bias evaluated with mixed model regression analysis, and this despite choice of milk yield as an input variable $(P \geq 0.62$; Tables 2,3 , and 4$)$. It was also the TDMI model developed by Huhtanen et al. (2011) that displayed the smallest RMSPE and the greatest CCC among the models evaluated with both mixed and simple regression (Tables 2, 3, and 4). Further, the mean and slope biases generally varied numerically depending on the estimate of milk yield applied as input variable for all TDMI prediction models, but least for the TDMI model developed by Huhtanen et al. (2011; Tables 2, 3, and 4). Generally, estimates of mean and slope biases were numerically comparable for all models evaluated with either mixed or simple regression analysis, but the random contribution to the prediction error increased with simple compared with mixed model regression analysis (Tables 2, 3, and 4). The CNCPS feed intake prediction model developed by Fox et al. (2004) showed greatest random contribution to the prediction error among all models (Tables 2, 3, and 4$)$.

\section{DISCUSSION}

\section{Model Performances}

The models chosen for evaluation in this study varied from rather simple models only including animal factors to more advanced and complex models comprising a variety of feed factors in addition to commonly used animal factors. Furthermore, the choice of models evaluated was also based on the adaptation of the model and whether it had been evaluated earlier. From this it would be possible to see if the performance was affected by time trends in diet compositon or ration formulation and dairy cow production potential. Unfortunately, we were restricted by the data required as model inputs from the experiments pooled in the database. Therefore, the newly developed models by Faverdin et al. (2011) and Zom et al. (2012a) that do not include current milk yield as an input variable in their predictions of feed intake were not evaluated in this study. Also, it was not possible to evaluate the model by Keady et al. (2004b), as it uses near infrared reflectance spectroscopy-predicted silage intake potential and body score as input variables.

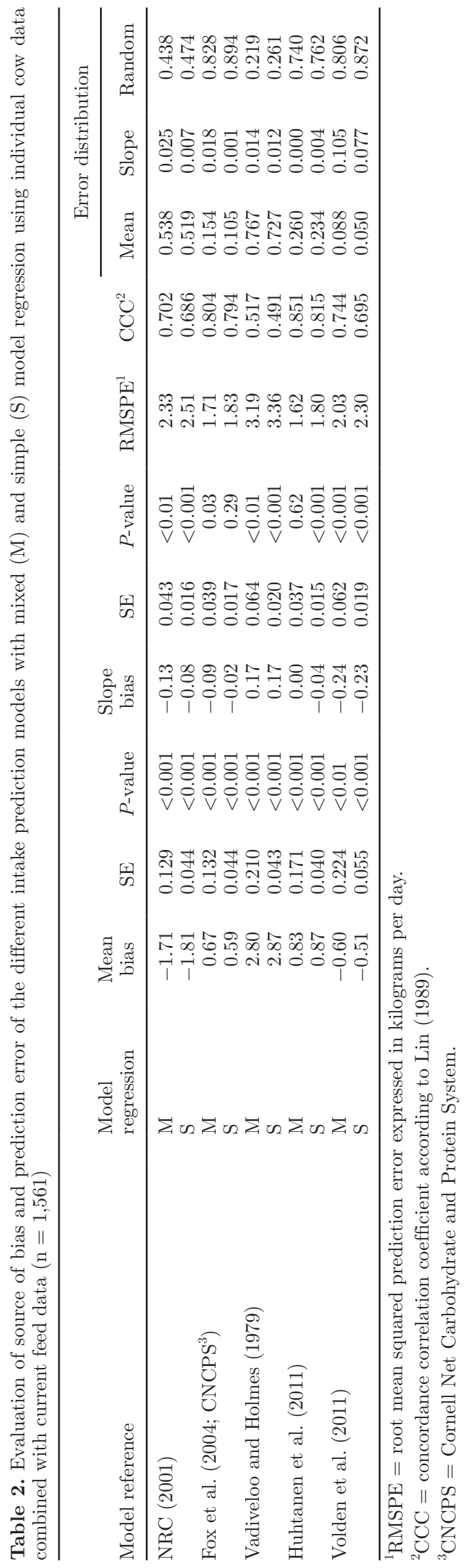


Table 3. Evaluation of source of bias and prediction error of the different intake prediction models with mixed (M) and simple (S) model regression using previous period individual cow data combined with current feed data $(\mathrm{n}=1,561)$

\begin{tabular}{|c|c|c|c|c|c|c|c|c|c|c|c|c|}
\hline \multirow[b]{2}{*}{ Model reference } & \multirow[b]{2}{*}{$\begin{array}{l}\text { Model } \\
\text { regression }\end{array}$} & \multirow[b]{2}{*}{$\begin{array}{c}\text { Mean } \\
\text { bias }\end{array}$} & \multirow[b]{2}{*}{$\mathrm{SE}$} & \multirow[b]{2}{*}{$P$-value } & \multirow[b]{2}{*}{$\begin{array}{c}\text { Slope } \\
\text { bias }\end{array}$} & \multirow[b]{2}{*}{$\mathrm{SE}$} & \multirow[b]{2}{*}{$P$-value } & \multirow[b]{2}{*}{$\mathrm{RMSPE}^{1}$} & \multirow[b]{2}{*}{$\mathrm{CCC}^{2}$} & \multicolumn{3}{|c|}{ Error distribution } \\
\hline & & & & & & & & & & Mean & Slope & Random \\
\hline \multirow[t]{2}{*}{ NRC (2001) } & M & -2.11 & 0.144 & $<0.001$ & -0.29 & 0.037 & $<0.001$ & 2.92 & 0.562 & 0.524 & 0.075 & 0.401 \\
\hline & $\mathrm{S}$ & -2.20 & 0.051 & $<0.001$ & -0.17 & 0.018 & $<0.001$ & 3.02 & 0.582 & 0.529 & 0.026 & 0.445 \\
\hline \multirow[t]{2}{*}{ Fox et al. $\left(2004 ; \mathrm{CNCPS}^{3}\right)$} & $\mathrm{M}$ & 0.35 & 0.147 & 0.03 & -0.24 & 0.038 & $<0.001$ & 1.96 & 0.731 & 0.032 & 0.100 & 0.868 \\
\hline & $\mathrm{S}$ & 0.27 & 0.050 & $<0.001$ & -0.12 & 0.019 & $<0.001$ & 2.03 & 0.745 & 0.018 & 0.022 & 0.960 \\
\hline \multirow[t]{2}{*}{ Vadiveloo and Holmes (1979) } & M & 2.66 & 0.203 & $<0.001$ & 0.14 & 0.065 & 0.04 & 3.11 & 0.520 & 0.731 & 0.010 & 0.260 \\
\hline & $\mathrm{S}$ & 2.71 & 0.045 & $<0.001$ & 0.16 & 0.021 & $<0.001$ & 3.26 & 0.499 & 0.690 & 0.011 & 0.299 \\
\hline \multirow[t]{2}{*}{ Huhtanen et al. (2011) } & $\mathrm{M}$ & 0.88 & 0.161 & $<0.001$ & -0.08 & 0.041 & 0.62 & 1.75 & 0.823 & 0.250 & 0.017 & 0.734 \\
\hline & $\mathrm{S}$ & 0.92 & 0.043 & $<0.001$ & -0.09 & 0.015 & $<0.001$ & 1.93 & 0.793 & 0.225 & 0.016 & 0.759 \\
\hline \multirow[t]{2}{*}{ Volden et al. (2011) } & $\mathrm{M}$ & -0.80 & 0.213 & $<0.01$ & -0.31 & 0.064 & $<0.001$ & 2.27 & 0.670 & 0.125 & 0.143 & 0.732 \\
\hline & $\mathrm{S}$ & -0.75 & 0.057 & $<0.001$ & -0.25 & 0.021 & $<0.001$ & 2.47 & 0.650 & 0.093 & 0.079 & 0.827 \\
\hline
\end{tabular}

${ }^{1} \mathrm{RMSPE}=$ root mean squared prediction error expressed in kilograms per day.

${ }^{2} \mathrm{CCC}=$ concordance correlation coefficient according to Lin (1989).

${ }^{3} \mathrm{CNCPS}=$ Cornell Net Carbohydrate and Protein System

Table 4. Evaluation of source of bias and prediction error of the different intake prediction models with mixed (M) and simple (S) model regression using average individual cow data across periods combined with current feed data $(\mathrm{n}=1,561)$

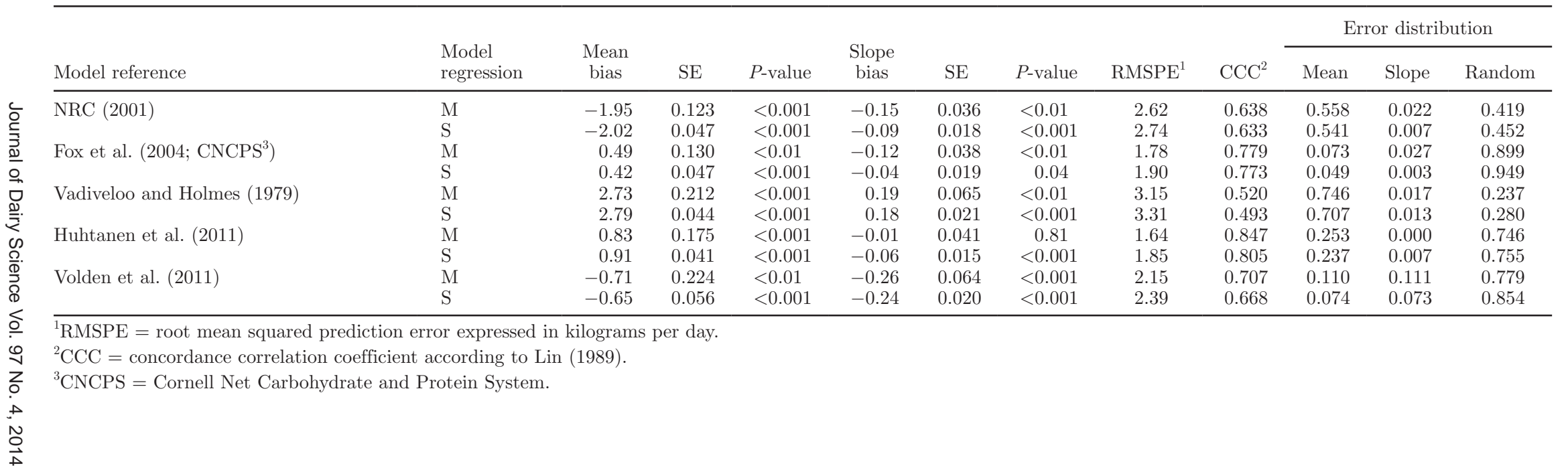


Previous as well as recent model evaluations in the literature have often been done using simple rather than mixed model regression analysis (Keady et al., 2004a; Zom et al., 2012b; Jensen et al., 2013). Any changes in regression coefficients and prediction errors between the mixed and simple model regression analyses in model evaluation will reflect the robustness of the model or differences in management factors between the experimental sites that are accounted for by the random study effect in the mixed model regression analysis. Among management factors of relevance in this kind of comparison, Huhtanen et al. (2011) mentioned feed analyses, feeding time or access to feed, TMR versus separate feeding, BCS influenced by prepartum management, and breed differences between the studies. In addition, Ingvartsen (1994) and Mertens (1994) mentioned tiestalls versus loose housing and environmental factors, such as temperature and photoperiod. As these factors are constant within study, Huhtanen et al. (2011) concluded that the true prediction error in practical conditions are closer to the mixed model rather than the simple model mean prediction error. The performance of the 5 models evaluated in this study were ranked the same using either mixed or simple model regression analysis, but generally the random contribution to the prediction error and the RMSPE increased with simple rather than mixed model regression analysis.

The TDMI model by Huhtanen et al. (2011) performed best judged from lowest RMSPE, highest CCC, and nonsignificant slope bias when evaluated from mixed model regression and when using the observed milk yield in the predictions. This was in agreement with the results of the study conducted by Jensen et al. (2013), who observed a mean bias of $0.21 \mathrm{~kg} / \mathrm{d}$ and a slope bias of 0.10, as well as an RMSPE of 1.4 $\mathrm{kg} / \mathrm{d}$ of the TDMI model developed by Huhtanen et al. (2011). The mean bias in the current study indicated an under-prediction of the TDMI and we hypothesized that the under-prediction was a consequence of feeding technique (i.e., TMR vs. separate feeding). The model by Huhtanen et al. (2011) was mainly developed from trials where forage and concentrates were fed separately in tiestall systems; feeding forages and concentrates as a TMR has been shown to increase DMI as opposed to when they are fed separately (Maltz et al., 1992). In several experiments included in this database diets were fed as a TMR. Contrary to our results, the mean bias in the study of Jensen et al. (2013) indicated an over-prediction of the TDMI. Their data material originated from both tiestalls and loose housing, and the diets were provided solely as a TMR. In addition, the data set by Jensen et al. (2013) consisted of many rations based on corn and alfalfa silage, which were diets not characteristic of the data used by Huhtanen et al. (2011) in the development of the model.

Despite the fact that the TDMI model by Fox et al. (2004) is based entirely on animal factors, it performed second best in our evaluation. The model displayed a positive mean bias indicating a general under-prediction of observed TDMI in agreement with the evaluation by Huhtanen et al. (2011). The poorer accuracy of prediction by the Fox et al. (2004) model in the present data set is probably because the model does not include any feed factors or because it was developed using data from high-producing Holstein Friesian cows offered rations largely based on corn silage and alfalfa silage, which are characteristics of dairy production systems in the United States.

The model by Volden et al. (2011) generally overpredicted TDMI in this evaluation, which was not in agreement with the mean bias of $0.03 \mathrm{~kg} / \mathrm{d}$ as assessed by Jensen et al. (2013). However, a negative slope bias was observed both in this study and in the evaluation conducted by Jensen et al. (2013), indicating that the over-prediction of the TDMI increased with level of feeding. When calculated according to St-Pierre (2003), the linear bias (slope $=-0.26 \pm 0.064, P<0.001$ ) implies a bias of $1.2 \mathrm{~kg} / \mathrm{d}$ at the minimum $(14.1 \mathrm{~kg} / \mathrm{d})$ and $-3.2 \mathrm{~kg} / \mathrm{d}$ at the maximum $(31.3 \mathrm{~kg} / \mathrm{d})$ predicted DMI. In a previous evaluation [S. J. Krizsan, A. Höjer, A. Huuskonen (MTT Agrifood Research Finland, Animal Production Research, Rukki, Finland), M. Hetta (Swedish University of Agricultural Sciences, Department of Agricultural Research for Northern Sweden, Umeå, Sweden), and P. Huhtanen, unpublished data], using a treatment mean data set $(n=828)$, the inability of the NorFor feed intake model to correct for increased substitution of forage with increased level of concentrate feeding was given as the main reason for the increased over-prediction of intake with level of feeding by the Volden et al. (2011) model.

The over-prediction of the TDMI by the NRC (2001) model in this study was in agreement with the evaluations by Huhtanen et al. (2011), Zom et al. (2012b), and Jensen et al. (2013). Huhtanen et al. (2011) showed that the precision of the predictions by the NRC (2001) and CNCPS (Fox et al., 2004) models was improved by including the TDMI index as a second independent variable in addition to the model-predicted TDMI in the model. This further illustrates that models entirely based on animal variables are not able to encompass the complexity of factors affecting feed intake in dairy cows (Ingvartsen, 1994). Further, the NRC (2001) model is similar to the CNCPS feed intake model by Fox et al. (2004) developed from data displaying typical characteristics of dairy production systems in the United States. 
The model by Vadiveloo and Holmes (1979) displayed the poorest performance of all models in this study. This is in agreement with the evaluation by Huhtanen et al. (2011) and Zom et al. (2012b), who also observed large positive mean and slope biases in the predictions of feed intake by the Vadiveloo and Holmes (1979) model. In the evaluation by Keady et al. (2004a), the Vadiveloo and Holmes (1979) model provided the most accurate predictions of feed intake among 5 evaluated models. The under-prediction of feed intake by the Vadiveloo and Holmes (1979) model (also under-prediction increased with increased level of feeding) is likely related to the changes in breeding and genetic potential of the dairy cows from the 1970s until today. Furthermore, also as discussed by Zom et al. (2012b), the conditions for which the feed intake model by Vadiveloo and Holmes (1979) were developed under is probably more in agreement with the data set of Keady et al. (2004a) than the data of the curret study or of Huhtanen et al. (2011) and Zom et al. (2012b).

\section{Milk Yield as Model Input}

One aim of the current study was to investigate how different estimates of the cow's milk yield will affect the feed intake predictions by the different models. Huhtanen and Nousiainen (2012) observed that $82 \%$ of the variation in ECM yield was related to DMI in a data set consisting of 1,116 treatment means. Due to the close correlation to intake, milk yield is often used as an animal factor in feed intake predictions. Ingvartsen (1994) stated that milk yield is not known at the time of prediction. The milk yield is a function of both the genetic merit of the cow and the quality of the diet (Zom et al., 2012a). The effects of the potential of the cow and of the diet on milk yield is not distinguishable when using observed milk yield in feed intake predictions. By using previous period individual cow data combined with current feed data in the evaluation of the feed intake prediction models we wanted to illustrate the on-farm situation when formulating new rations for lactating cows. The ranking of the performance of the models did not change, but the prediction error of all models was greater when using previous period data compared with the actual observed milk yield, except for the model by Vadiveloo and Holmes (1979) for which the RMSPE numerically decreased. This is explained by the positive slope bias of the model by Vadiveloo and Holmes (1979) that indicated less under-prediction at lower levels of feed intake.

The models using the current milk yield are primarily useful in predicting intake required to sustain a given level of milk yield, as stated by Keady et al. (2004a). However, using observed milk yield in predicting future intake, as shown in the current study, resulted in a greater error than previous evaluations in the literature have suggested when evaluating feed intake models with mixed model regression analysis [Huhtanen et al., 2011; S. J. Krizsan, A. Höjer, A. Huuskonen (MTT Agrifood Research Finland, Animal Production Research, Rukki, Finland), M. Hetta (Swedish University of Agricultural Sciences, Department of Agricultural Research for Northern Sweden, Umeå, Sweden), and P. Huhtanen, unpublished data]. Greater differences between observed and predicted feed intake can also be attributed to the use of individual cow data rather than treatment mean data (Huhtanen et al., 2011). Furthermore, using milk yield as an input variable can result in seriously biased predictions if the economically optimal diet deviates from the current one, as the study by Friggens et al. (1998) demonstrated. Friggens et al. (1998) investigated the effect of stage of lactation on TDMI by applying a low- and high-concentrate diet feeding regimen to lactating cows. During lactation they switched the diets between the experimental cows, which clearly illustrated the effect of TDMI on milk production when the diet was constraining intake rather than the production requirements of the cow.

Regarding the greater milk yield for cows fed the high-concentrate diet, feed intake predictions based on the observed milk yield would have predicted a greater TDMI after changing to the low-concentrate diet compared with those cows fed the low-concentrate diet continously. This indicates that the difference in milk yield was a function of the diet rather than the cow's production potential. The average difference in milk yield between the 2 diets was $7.2 \mathrm{~kg} / \mathrm{d}$ across the whole experiment (Friggens et al., 1998). A similar illustration of the effect of diet composition on intake and milk production can bee seen in the study by Law et al. (2009). They investigated the optimal dietary CP concentrations in early and mid lactation by allocating half of the animals in each treatment group to an alternative dietary $\mathrm{CP}$ concentration. When the average milk yield over all periods were used in the predictions of feed intake in the current study, the increase in the prediction error of all models was less than when compared with combining previous period individual animal data with current feed data. The feed intake predictions using the TDMI model by Huhtanen et al., (2011) was least affected by the different estimates of milk yield as an input variable when compared with the observed values of intake. Huhtanen et al. (2011) developed an sECM to be used as an input variable in predictions of TDMI. The sECM can be estimated before feeding and is adjusted to current diet compositon and DIM to represent a potential rather than observed milk yield. Unfortunately, we could not evaluate the model devel- 
oped by Zom et al. (2012a) that completely excluded milk yield as an input variable in the predictions of TDMI. That model predicted TDMI without any bias and was most accurate among the evaluated models by Zom et al. (2012b). This was strongly in contrast with the results of Jensen et al. (2013), where the model by Zom et al. (2012a) was least accurate of the evaluated models, and a substantial proportion of the prediction error was contributed by mean and slope bias.

\section{CONCLUSIONS}

None of the evaluated feed intake model in this study provide completely unbiased estimates of feed intake. The interaction between environmental, feed, and animal factors seems to limit the use and affect the evaluation of any empirical intake model. However, using a standardized milk yield improved the predictions of feed intake and provided a more robust model. Prediction errors of earlier evaluations of dairy cow feed intake models using the observed treatment mean milk yield in mixed model regression analysis are likely underestimated with regard to the data available when formulating rations for dairy cows in practise. Using observed milk yield as a model input in predictions of feed intake can be substantially affected by dietary factors. However, the standardized milk yield improved the predictions of feed intake and provided a more robust model reflecting the potential of the cow. Milk yield as model input can be used when formulating new rations aiming to sustain a given milk yield, but can generate large errors in estimates of future feed intake and milk production if the economically optimal diet deviates from the current diet.

\section{ACKNOWLEDGMENTS}

The authors acknowledge the Regional Farmers' Foundation for Agricultural Research in Northern Sweden for financial support of the project. The authors further thank J. Bertilsson (Swedish University of Agricultural Sciences, Uppsala, Sweden), H. Gidlund (Swedish University of Agricultural Sciences, Umeå, Sweden), T. Heikkilä (MTT Agrifood Research Finland, Jokioinen, Finland), M. Hetta (Swedish University of Agricultural Sciences, Umeå, Sweden), S. Jaakkola (Helsinki University, Helsinki, Finland), E. Prestløkken and A. T. Randby (both from Norwegian University of Life Sciences, Âs, Norway), M. Rinne and K. Shingfield (both from MTT Agrifood Research Finland, Jokioinen, Finland), J. Wallsten (Swedish University of Agricultural Sciences, Umeå, Sweden), and M. R. Weisbjerg (Aarhus University, Aarhus, Denmark) that have complemented published data or contributed with unpublished data.

\section{REFERENCES}

Bibby, J., and H. Toutenberg. 1977. Prediction and improved estimation in linear models. John Wiley \& Sons Ltd., Chichester, UK.

Faverdin, P., C. Baratte, R. Delagarde, and J. L. Peyraud. 2011. GrazeIn: A model of herbage intake and milk production for grazing dairy cows. 1. Prediction of intake capacity, voluntary intake and milk production during lactation. Grass Forage Sci. 66:29-44.

Fox, D. G., L. O. Tedeschi, T. P. Tylutki, J. B. Russell, M. E. Van Amburgh, L. E. Chase, A . N. Pell, and T. R. Overton. 2004. The Cornell Net Carbohydrate and Protein System model for evaluating herd nutrition and nutrient excretion. Anim. Feed Sci. Technol. 112:29-78.

Friggens, N. C., G. C. Emmans, I. Kyriazakis, J. D. Oldham, and M. Lewis. 1998. Feed intake relative to stage of lactation for dairy cows consuming total mixed diets with a high or low ratio of concentrate to forage. J. Dairy Sci. 81:2228-2239.

Huhtanen, P., H. Khalili, J. I. Nousiainen, M. Rinne, S. Jaakkola, T. Heikkila, and J. Nousiainen. 2002. Prediction of the relative intake potential of grass silage by dairy cows. Livest. Prod. Sci. 73:111-130.

Huhtanen, P., and J. Nousiainen. 2012. Production responses of lactating dairy cows fed silage-based diets to changes in nutrient supply. Livest. Sci. 148:146-158.

Huhtanen, P., M. Rinne, P. Mäntysaari, and J. Nousiainen. 2011. Integration of the effects of animal and dietary factors on total dry matter intake of dairy cows fed silage-based diets. Animal 5:691-702.

Huhtanen, P., M. Rinne, and J. Nousiainen. 2007. Evaluation of the factors affecting silage intake of dairy cows: A revision of the relative silage dry-matter intake index. Animal 1:758-770.

Huhtanen, P., M. Rinne, and J. Nousiainen. 2008. Evaluation of concentrate factors affecting silage intake of dairy cows: A development of the relative total diet intake index. Animal 2:942-953.

Ingvartsen, K. L. 1994. Models of voluntary food intake in cattle. Livest. Prod. Sci. 39:19-38.

Jensen, L. M., N. I. Nielsen, B. Markussen, and P. Nørgaard. 2013. Comparison of feed intake models for dairy cows. Pages 87-92 in Proc. 4th Nordic Feed Sci. Conf. Uppsala, Sweden, June 12-13, 2013. SLU Repro, Uppsala, Sweden.

Keady, T. W. J., C. S. Mayne, and D. J. Kilpatrick. 2004a. An evaluation of five models commonly used to predict food intake of lactating dairy cattle. Livest. Prod. Sci. 89:129-138.

Keady, T. W. J., C. S. Mayne, N. W. Offer, and C. Thomas. 2004b. Prediction of voluntary intake. Pages $1-7$ in Feed into Milk-A New Applied Feeding System for Dairy Cows. C.Thomas, ed. Nottingham University Press, Nottingham, UK.

Law, R. A., F. J. Young, D. C. Patterson, D. J. Kilpatrick, A. R. G. Wylie, and C. S. Mayne. 2009. Effects of dietary protein content on animal production and blood metabolites of dairy cows during lactation. J. Dairy Sci. 92:1001-1012.

Lin, L. I. K. 1989. A concordance correlation coefficient to evaluate reproducibility. Biometrics 45:255-268.

Maltz, E., S. Devir, O. Kroll, B. Zur, S. L. Spahr, and R. D. Shanks. 1992. Comparative responses of lactating cows to total mixed rations or computerized individual concentrates feeding. J. Dairy Sci. $75: 1588-1603$.

Mertens, D. R. 1994. Regulation of forage intake. Pages 450-493 in Forage Quality, Evaluation and Utilization. G. C. Fahey Jr., ed. American Society of Agronomy Inc., Crop Science Society of America Inc., Soil Science Society of America Inc., Madison, WI.

MTT. 2012. Feed tables and nutrient requirements. MTT Agrifood Research Finland, Jokioinen, Finland. Accessed July 30, 2013. http://www.mtt.fi/feedtables.

NorFor. 2013. NorFor Feedtable. Accessed July 24, 2013. http://www. norfor.info. 
NRC. 2001. Nutrient Requirements of Dairy Cattle. 7th rev. ed. Natl. Acad. Press, Washington, DC.

Sjaunja, L. O., L. Baevre, L. Junkkarinen, J. Pedersen, and J. Setala. 1990. A nordic proposal for an energy corrected milk (ECM) formula. Pages 156-192 in European Association for Animal Production Publication, Performance Recording of Animals: State of the Art, 1990; 27th Biennial Session of the International Committee for Animal Recording. P. Gaillon and Y. Chabert, ed. Centre for Agricultural Publishing and Documentation, Paris, France.

St-Pierre, N. R. 2003. Reassessment of biases in predicted nitrogen flows to the duodenum by NRC 2001. J. Dairy Sci. 86:344-350.

Vadiveloo, J., and W. Holmes. 1979. The prediction of the voluntary feed intake of dairy cows. J. Agric. Sci. Camb. 93:553-562.

Volden, H., N. I. Nielsen, M. Åkerlind, M. Larsen, Ø. Havrevoll, and A. J. Rygh. 2011. Prediction of voluntary feed intake. Pages 113-132 in Norfor-The Nordic Feed Evaluation System. H. Volden, ed. Wageningen Academic Publishers, Wageningen, the Netherlands.

Zom, R. L. G., G. André, and A. M. van Vuuren. 2012a. Development of a model for the prediction of feed intake by dairy cows: 1 . Prediction of feed intake. Livest. Sci. 143:43-57.

Zom, R. L. G., G. André, and A. M. van Vuuren. 2012b. Development of a model for the prediction of feed intake by dairy cows: 2. Evaluation of prediction accuracy. Livest. Sci. 143:58-69.

\section{APPENDIX}

\section{List of References of the Experiments Used for the Meta-Analysis}

Bertilsson, J., and M. Murphy. 2003. Effects of feeding clover silage on feed intake, milk production and digestion in dairy cows. Grass Forage Sci. 58:309-322.

Gidlund, H., M. Hetta, S. J. Krizsan, S. Lemosquet, and P. Huhtanen. 2013. New recommendations of the ruminal in situ determination of indigestible neutral detergent fiber with special reference to near infrared reflectance spectroscopy. Pages 104-108 in Proc. 4th Nordic Feed Sci. Conf., SLU Repro, Uppsala, Sweden.

Heikkilä, T., E. Saarisalo, A.-M. Taimisto, and S. Jaakkola. 2010. Effects of dry matter and additive on wilted bale silage quality and milk production. Grassl. Sci. Europe 15:500-502.

Hetta, M., M. N. Tahir, S. J. Krizsan, A. Puranen, P. Lund, and P. Huhtanen. 2013. Effects of the inclusion of sodium hydroxide treated wheat on the voluntary feed intake and milk production in dairy cows. Livest. Sci. 154:103-111.

Höjer, A., S. Adler, K. Martinsson, S. K. Jensen, H. Steinshamn, E. Thuen, and A.-M. Gustavsson. 2012. Effect of legume-grass silages and $\alpha$-tocopherol supplementation on fatty acid composition and $\alpha$-tocopherol, $\beta$-carotene and retinol concentrations in organically produced bovine milk. Livest. Sci. 148:268-281.

Hymøller, L., M. R. Weisbjerg, P. Nørgaard, C. F. Børsting, and N. B. Kristensen. 2005. Majsensilage til malkekøer (Corn silage to dairy cows). DJF rapport Husdyrbrug nr. 65. Ministeriet for Fødevarer, Landbrug og Fiskeri. Danmarks JordbrugsForskning, Tjele, Denmark. (In Danish).

Jaakkola, S., E. Saarisalo, and T. Heikkilä. 2009. Formic acid treated whole crop barley and wheat silages in dairy cow diets: Effects of crop maturity, proportion in the diet, and level and type of concentrate supplementation. Agric. Food Sci. 18:234-256.

Jaakkola, S., E. Saarisalo, T. Heikkilä, M. Nysand, A. Suokannas, M. Mäki, and A.-M. Taimisto. The effect of silage making tech- nology on production and quality of milk. Grassl. Sci. Europe 13:642-644.

Kuoppala, K., M. Rinne, J. Nousiainen, and P. Huhtanen. 2008. The effect of cutting time of grass silage in primary growth and regrowth and the interactions between silage quality and concentrate level on milk production of dairy cows. Livest. Sci. 116:171-182.

Prestløkken, E., A. T. Randby, and T. Garmo. 2008. Effect of harvesting time and wilting on feed intake and production by dairy cows. Pages 849-851 in Biodiversity and Animal Feed: Future Challenges for Grassland Production. Proceedings of the 22nd General Meeting of the European Grassland Federation, SLU Repro, Uppsala, Sweden.

Randby, Å. T., T. Garmo, M. Eknæs, and E. Prestløkken. Effects of grass silage chop length on intake and milk production by dairy cows. 2008. Pages 768-770 in Biodiversity and Animal Feed: Future Challenges for Grassland Production. Proceedings of the 22nd General Meeting of the European Grassland Federation, SLU Repro, Uppsala, Sweden.

Rinne, M., S. Jaakkola, K. Kaustell, T. Heikkilä, and P. Huhtanen. 1999. Silages harvested at different stages of grass growth versus concentrate foods as energy and protein sources in milk production. Anim. Sci. 69:251-263.

Saarisalo, E., S. Jaakkola, and P. Huhtanen. 2002. Effects of supplementing grass silage with protein on production of primiparous cows in late lactation. Grassl. Sci. Europe 7:594-595.

Sairanen, A. 2011. Säilörehun sulavuuden sekä väkirehu- ja valkuaistäydennyksen vaikutukset maidontuotannossa (The interaction between harvest time, concentrate supplementation and protein supplementation on milk production). Accessed Jan. 29, 2014. http:// hdl.handle.net/10138/27425.

Sairanen A., and E. Juutinen. 2012. Nurmesta se kaikki lähtee! Karjatilan kannattava peltoviljely KARPE-hanke 2009-2012. Final report, pages 11-16. Page 12, experiments 2 and 5. Accessed Jan. 29, 2014. http://www.karpe.fi/materiaalit/karpekirjasto/paatosjulkaisu.pdf.

Sairanen, A., and E. Juutinen. 2013. Feeding value of late autumn cut timothy-meadow fescue silage under Northern conditions. EGF Iceland.

Sairanen, A., J. I. Nousiainen, and H. Khalili. 1999. Korkean väkirehumäärän vaikutus maitotuotokseen ja tuotannon kannattavuuteen (The effect of protein and concentrate supplementation on milk production performance of dairy cows). Accessed Jan. 29, 2014. http://jukuri.mtt.fi/handle/10024/445044.

Shingfield, K., S. Jaakkola, and P. Huhtanen. 2002. Effect of forage conservation method, concentrate level and propylene glycol on intake, feeding behavior and milk production of dairy cows. Anim. Sci. 74:383-397.

Shingfield, K., S. Jaakkola, and P. Huhtanen. 2003. Comparison of heat-treated rapeseed expeller and solvent-extracted soya-bean meal protein supplements for dairy cows given grass silage-based diets. Anim. Sci. 77:305-317.

Wallsten, J. 2012. Så funkar vårvete som helsäd i norra Sverige (Spring wheat as whole crop silage in northern Sweden). Grovfoderkonferensen 2013. Rapport 2:2013 vid Institutionen för norrländsk jordbruksvetenskap, Sveriges lantbruksuniversitet i Umeå. (In Swedish).

Weisbjerg, M. R., L. Wiking, N. B. Kristensen, and P. Lund. 2008. Effects of supplemental dietary fatty acids on milk yield and fatty acid composition in high and medium yielding cows. J. Dairy Res. $75: 142-152$. 